\title{
Distribution and Severity of Pasmo on Flax in North Dakota and Evaluation of Fungicides and Cultivars for Management
}

\author{
S. Halley, Langdon Research Extension Center, C. A. Bradley, Department of Plant Pathology, North Dakota State \\ University, Fargo 58105; and J. R. Lukach, Langdon Research Extension Center, North Dakota State University, \\ Langdon 58249; M. McMullen, Department of Plant Pathology, North Dakota State University, Fargo 58105; \\ J. J. Knodel, North Central Research Extension Center, North Dakota State University, Minot 58701; G. J. Endres, \\ Carrington Research Extension Center, North Dakota State University, Carrington 58421; and T. Gregoire, North \\ Dakota State University Extension Service, Devils Lake 58301
}

\begin{abstract}
Halley, S., Bradley, C. A., Lukach, J. R., McMullen, M., Knodel, J. J., Endres, G. J., and Gregoire, T. 2004. Distribution and severity of pasmo on flax in North Dakota and evaluation of fungicides and cultivars for management. Plant Dis. 88:1123-1126.

Pasmo, caused by Septoria linicola, reduces flax (Linum usitatissimum) yield in the Canadian provinces of Manitoba and Saskatchewan, but little is known about its distribution and effect on yield in North Dakota. Field surveys for pasmo were conducted in 74 and 87 flax fields across 19 and 23 North Dakota counties in 2002 and 2003, respectively. The surveys indicated that pasmo was present in 17 and 18 counties in 2002 and 2003, respectively. County mean plant incidences ranged from 0 to $21 \%$ and 0 to $84.5 \%$ in 2002 and 2003, respectively. County mean pasmo severity ranged from 0 to $38.8 \%$ and 0 to $29.3 \%$ in 2002 and 2003 , respectively. Significant $(P \leq 0.07)$ positive Pearson correlations were detected between total rainfall accumulated for June to August and pasmo severity in 2002 and 2003 and for rainfall and pasmo incidence in 2003. Field trials were conducted to determine the effect of fungicides and flax cultivars on pasmo severity and flax yield. Pasmo severity was significantly $(P \leq 0.05)$ reduced with azoxystrobin and sulfur fungicides compared with the untreated control. Flax yields were significantly $(P \leq 0.05)$ greater in azoxystrobin- and prothioconazole-treated plots than in the untreated control plots. Cv. Omega had significantly lower pasmo severity than the other three cultivars, but cv. Rahab 94 had the greatest yield of all the cultivars. Based on the results presented, pasmo is an important disease of flax in North Dakota, and its distribution is widespread throughout the flax-production region. Fungicides such as azoxystrobin and prothioconazole appear to be excellent potential tools for pasmo management.
\end{abstract}

Additional keywords: JAU 6476, Microthiol Disperss, Quadris, Ronilan

Production of flax (Linum usitatissimum L.) in North Dakota increased from 32,275 ha in 1996 to nearly 300,000 ha in 2002 (North Dakota Agricultural Statistics Service, Fargo, ND). The increased production is partially due to the inclusion of flax in rotations as a broadleaf alternative to cereal crops and its apparent reduced field susceptibility to Sclerotinia sclerotiorum compared with most other broadleaf crops grown in North Dakota. Although flax appears to be less susceptible to $S$. sclerotiorum, it is susceptible to other potentially significant diseases. Pasmo, caused by Septoria linicola (Speg.) Garassini, is known to occur often in the Canadian

Corresponding author: C. A. Bradley

E-mail: carl.bradley@ndsu.nodak.edu

This project was funded by a grant from the North Dakota Oilseed Council.

Accepted for publication 3 June 2004.

Publication no. D-2004-0723-02R

(C) 2003 The American Phytopathological Society provinces of Manitoba and Saskatchewan (6), but little is known about its distribution and effect on yield in North Dakota. Disease symptoms of pasmo begin as brown spots on the leaves. The infections move from the leaves to the stem at the point of attachment, which causes brown to black bands on the stem that alternate with green healthy bands, giving a "barbershop pole" appearance. Flax yields in Manitoba have been reported to be reduced by pasmo up to $70 \%$ (3). Because most flax cultivars are susceptible to pasmo, fungicides may be a potential method of managing the disease on flax. The objectives of this study were to (i) conduct field surveys for pasmo distribution in North Dakota and (ii) evaluate the effect of fungicides and cultivars on pasmo and flax yield.

\section{MATERIALS AND METHODS}

Survey. In all, 74 and 87 flax fields in 19 and 23 North Dakota counties were surveyed when plants were between growth stages 11 and 12 (brown capsule to ripe seed) in 2002 and 2003, respectively.
The counties and number of fields within each county are listed in Tables 1 and 2 and the geographical distribution of these counties is illustrated in Figure 1. The number of fields surveyed per county was based on flax acreage in each county. An attempt was made to survey one field for every 4,050 planted hectares of flax. In 2002, 20 consecutive plants in a row from five different locations in each field (100 plants total per field) were examined for pasmo symptoms. In 2003, 10 consecutive plants in a row from five different locations in each field (50 plants total per field) were examined for pasmo symptoms. Pasmo symptoms consisted of brown to black alternating bands on the stem. Field incidence was calculated by totaling the number of plants with symptoms and converting to percent. The pasmo severity rating represents an average severity for the total number of plants examined in each field, and was determined by estimating the percentage of the stem covered with lesions. Pasmo severity was not evaluated for fields in Cavalier, Towner, and Walsh counties in 2002. Rainfall data were collected each year for surveyed counties for the months of June, July, and August using the North Dakota Agricultural Weather Network (North Dakota State University, Fargo, ND). Relationships between rainfall and pasmo incidence and severity were evaluated by conducting Pearson correlations (PROC CORR) in SAS (SAS Institute, Inc., Cary, NC).

Fungicide-cultivar evaluation. In 2002 and 2003, field trials were established in Langdon, ND (Cavalier County) to evaluate fungicides for pasmo control on different flax cultivars. The trials consisted of five fungicide treatments, which were (i) an untreated control; (ii) prothioconazole (JAU 6476; Bayer CropScience, Research Triangle Park, NC) at $0.2 \mathrm{~kg}$ a.i./ha + nonionic surfactant (Induce; Helena Chemical Co., Collierville, TN) at $0.125 \%$ (vol/vol); (iii) azoxystrobin (Quadris; Syngenta Crop Protection, Inc., Greensboro, NC) at 0.17 kg a.i./ha; (iv) vinclozolin (Ronilan EG; BASF Corp., Research Triangle Park, NC) at $0.42 \mathrm{~kg}$ a.i./ha; and (v) sulfur (Microthiol Disperss; Cerexagri, Inc., King of 
Prussia, PA) at $4.49 \mathrm{~kg}$ a.i./ha. All fungicide treatments were evaluated on AC Watson, Omega, Rahab 94, and Webster flax cultivars. Plots were planted 7 May 2002 and 28 April 2003 and were seven rows wide and $5 \mathrm{~m}$ long, with $15-\mathrm{cm}$ row spacings. Plots were arranged as a factorial in a randomized complete block design with were planted between each plot to minimize fungicide drift onto other plots. To help ensure pasmo disease pressure, stems infected with $S$. linicola were distributed evenly in the alleys between plots after planting. Fungicides were applied 9 July four replications. Untreated border plots

2002 and 27 June 2003 prior to flowering with a $\mathrm{CO}_{2}$-pressurized backpack sprayer equipped with XR8002 flat-fan nozzles (Spraying Systems Co., Wheaton, IL) at 168 liters/ha and $276 \mathrm{kPa}$.

Twenty plants per plot were evaluated for pasmo severity on 19 July 2002 and 16 July 2003. Leaf symptoms were used to evaluate pasmo severity in the fungicidecultivar trials. Pasmo percent severity was calculated as (length of plant with symptomatic leaves from the soil line/total length of plant in centimeters) $\times 100$; for example, if a plant had leaf symptoms from the soil surface upward for $10 \mathrm{~cm}$ and the

Table 1. North Dakota flax fields surveyed, pasmo incidence and severity, and total average rainfall accumulated for June to August 2002

\begin{tabular}{|c|c|c|c|c|}
\hline County & No. of fields & Plant incidence (\%) & Severity $(\%)^{\mathbf{a}}$ & Rainfall $(\mathbf{m m})^{b}$ \\
\hline Bottineau & 5 & 0.6 & 5.0 & 229 \\
\hline Burke & 5 & 4.0 & 3.0 & 194 \\
\hline Cavalier & 4 & 2.5 & NA & 296 \\
\hline Divide & 1 & 0.0 & 0.0 & 188 \\
\hline Eddy & 2 & 1.5 & 2.0 & 201 \\
\hline Foster & 5 & 10.8 & 10.4 & 240 \\
\hline McHenry & 5 & 7.8 & 20.0 & 228 \\
\hline McLean & 6 & 14.7 & 1.0 & 186 \\
\hline Mountrail & 5 & 1.6 & 1.0 & 193 \\
\hline Pierce & 6 & 0.5 & 6.0 & NA \\
\hline Renville & 6 & 2.3 & 1.0 & 253 \\
\hline Rolette & 6 & 15.0 & 38.8 & 257 \\
\hline Sheridan & 1 & 6.0 & 14.4 & NA \\
\hline Stutsman & 4 & 5.3 & 4.9 & 259 \\
\hline Towner & 2 & 6.0 & NA & 311 \\
\hline Walsh & 2 & 3.0 & NA & 358 \\
\hline Ward & 6 & 1.0 & 1.0 & 205 \\
\hline Wells & 2 & 21.0 & 20.4 & 234 \\
\hline Williams & 1 & 0.0 & 0.0 & 170 \\
\hline Total fields/state mean & 74 & 5.5 & 8.1 & NA \\
\hline
\end{tabular}

${ }^{a}$ Pasmo severity was calculated by estimating percent stem with lesions. NA $=$ not available.

${ }^{b}$ Total average rainfall across weather stations within each county for June to August.

Table 2. North Dakota flax fields surveyed, pasmo incidence and severity, and total average rainfall accumulated for June to August 2003

\begin{tabular}{|c|c|c|c|c|}
\hline County & No. of fields & Plant incidence (\%) & Severity $(\%)^{a}$ & Rainfall $(\mathbf{m m})^{\mathbf{b}}$ \\
\hline Benson & 2 & 32.5 & 22.5 & 162 \\
\hline Bottineau & 6 & 1.0 & 0.8 & 109 \\
\hline Burke & 10 & 0.0 & 0.0 & 83 \\
\hline Cavalier & 4 & 12.5 & 8.8 & 151 \\
\hline Divide & 2 & 0.0 & 0.0 & 98 \\
\hline Eddy & 2 & 21.2 & 11.7 & 309 \\
\hline Foster & 3 & 52.3 & 17.2 & 226 \\
\hline Kidder & 1 & 5.0 & 22.0 & 95 \\
\hline McHenry & 2 & 5.0 & 2.5 & 197 \\
\hline McLean & 7 & 1.0 & 1.4 & 131 \\
\hline Mountrail & 9 & 0.0 & 0.0 & 108 \\
\hline Nelson & 1 & 0.0 & 0.0 & 149 \\
\hline Pierce & 2 & 5.0 & 7.5 & NA \\
\hline Ramsey & 2 & 20.0 & 15.0 & 273 \\
\hline Renville & 5 & 3.6 & 2.0 & 171 \\
\hline Rolette & 2 & 10.0 & 7.5 & 101 \\
\hline Sheridan & 3 & 36.3 & 12.7 & NA \\
\hline Stutsman & 2 & 84.5 & 29.3 & 147 \\
\hline Towner & 3 & 32.7 & 20.0 & 161 \\
\hline Walsh & 2 & 10.0 & 5.0 & 146 \\
\hline Ward & 13 & 0.2 & 0.3 & 59 \\
\hline Wells & 2 & 74.5 & 26.0 & 213 \\
\hline Williams & 2 & 0.0 & 0.0 & 92 \\
\hline Total fields/state mean & 87 & 17.7 & 9.2 & NA \\
\hline
\end{tabular}

${ }^{\text {a }}$ Pasmo severity was calculated by estimating percent stem with lesions.

${ }^{\mathrm{b}}$ Total average rainfall across weather stations within each county for June to August. NA = not available. plant was $50 \mathrm{~cm}$ tall, the disease severity would be $20 \%$. Plots were harvested with a small plot combine on 4 September 2002 and 20 August 2003 and grain yields were determined. Data were statistically analyzed using the general linear model procedure (PROC GLM) in SAS. Fisher's protected least significant difference was used to compare means at the $5 \%$ probability level.

\section{RESULTS}

2002 survey. County mean plant incidences of pasmo ranged from 0 to $21 \%$ (Table 1). Pasmo was not detected in surveyed fields in Divide and Williams counties. Counties with a mean pasmo plant incidence of $10 \%$ or greater were Foster $(10.8 \%)$, McLean $(14.7 \%)$, Rolette $(15 \%)$, and Wells $(21 \%)$. Mean plant pasmo incidence in the other 13 counties ranged from $0.5 \%$ to $7.8 \%$. The state mean pasmo plant incidence was $5.5 \%$. Total average rainfall accumulated for June to August for each surveyed county ranged from 170 to 358 $\mathrm{mm}$. The Pearson correlation coefficient between pasmo incidence and rainfall was 0.08 , but was not significant $(P=0.7717)$.

County mean pasmo severity ranged from 0 to $38.8 \%$ (Table 1). Mean pasmo severity of $20 \%$ or greater occurred in McHenry (20\%), Rolette (38.8\%), and Wells $(20.4 \%)$ counties. Mean pasmo severity between 10 and $19 \%$ occurred in Foster (10.4\%) and Sheridan (14.4\%) counties. Mean pasmo severity for nine other counties in which pasmo occurred and severity ratings were collected ranged from 1 to $6 \%$. The state mean pasmo severity was $8.1 \%$. The Pearson correlation coefficient between pasmo severity and rainfall was 0.58 and was significant at $P=0.03$.

2003 survey. County mean plant incidences of pasmo ranged from 0 to $84.5 \%$ (Table 2). Burke, Divide, Mountrail, Nelson, and Williams counties had no mean plant incidence of pasmo. Three counties had a mean pasmo plant incidence between 10 and 19\%: Cavalier (12.5\%), Rolette $(10 \%)$, and Walsh (10\%). Eight counties had a mean pasmo plant incidence of $20 \%$ or greater: Benson (32.5\%), Eddy (21.2\%), Foster $(52.3 \%)$, Ramsey (20\%), Sheridan (36.3\%), Stutsman (84.5\%), Towner $(32.7 \%)$, and Wells $(74.5 \%)$. Mean pasmo plant incidence for the other eight counties ranged from 0.2 to $5 \%$. The state mean pasmo plant incidence was $17.7 \%$. Total average rainfall accumulated for June to August for each surveyed county ranged from 59 to $309 \mathrm{~mm}$. The Pearson correlation coefficient between pasmo incidence and rainfall was 0.44 and was significant at $P=0.0474$.

County mean pasmo severity ranged from 0 to $29.3 \%$ (Table 2). Mean pasmo severity of $20 \%$ or greater occurred in Benson (22.5\%), Kidder (22\%), Stutsman $(29.3 \%)$, Towner $(20 \%)$, and Wells $(26 \%)$ 
counties. Mean pasmo severity between 10 and $19 \%$ occurred in Eddy $(11.7 \%)$, Foster (17.2\%), Ramsey (15\%), and Sheridan $(12.7 \%)$ counties. Mean pasmo severity in the nine other counties with symptoms ranged from 0.3 to $8.8 \%$. The state mean pasmo severity was $9.2 \%$. The Pearson correlation coefficient between pasmo severity and rainfall was 0.41 and was significant at $P=0.0631$.

Fungicide-cultivar evaluation. Because no significant $(P \leq 0.05)$ interactions were detected, data from each year were combined and main effects only are presented. Significant variation among fungicides occurred for pasmo severity $(P=$ $0.0001)$ and flax yield $(P=0.0001)$. Plots treated with azoxystrobin had significantly less pasmo severity than any other fungicide and the untreated control (Table 3). Plots treated with sulfur had significantly less pasmo severity than the untreated control. Yield was significantly greater in azoxystrobin-treated plots than in any other fungicide-treated plot and the untreated control. Prothioconazole-treated plots had a significantly greater yield than the untreated control plots.

Significant variation among flax cultivars for pasmo severity $(P=0.0001)$ and yield $(P=0.0001)$ occurred. $\mathrm{Cv}$. Omega had significantly less pasmo severity than any other cultivar (Table 4). Cvs. Webster and Rahab 94 had significantly less pasmo severity than cv. AC Watson. Rahab 94 had significantly greater yield than any other cultivar. AC Watson had significantly greater yield than Omega and Webster.

\section{DISCUSSION}

Pasmo was found throughout the surveyed North Dakota counties in both years of the survey. Surveys of flax fields in Manitoba and Saskatchewan have shown that 58 to $96 \%$ of flax fields had pasmo symptoms from 1996 to 2002 (5-7,9-12). Significant positive correlations were detected between pasmo incidence and severity and total rainfall accumulated from June to August. Pasmo is spread by pycnidiaspores that are moved primarily by splashing rain (4). Because of the dependence on rainfall for disease spread, these observed correlations were not unexpected.
In our field trials, azoxystrobin, a quinone outside inhibitor (QoI) fungicide, significantly decreased pasmo severity and increased flax yield compared with the untreated control. This is the first report of a QoI fungicide having efficacy against pasmo on flax. Future evaluations of fungicides for pasmo control should include other recently developed QoI fungicides. In our field trials, sulfur significantly decreased pasmo severity, but did not increase yield compared with the untreated control. The lack of yield increase with sulfur may have been due to minor phytotoxicity to flax. Sulfur-based fungicides have been shown to be phytotoxic to other plants, such as muskmelon (Cucumis melo) (14), apple (Malus $\times$ domestica) (2), and dogwood (Cornus florida) (13). Although prothioconazole did not significantly decrease pasmo severity in our field trials, it did significantly increase yield compared with the untreated control. Prothioconazole is a sterol biosynthesis inhibitor and class I demethylation inhibitor fungicide, as is propiconazole. Propiconazole significantly increased flax yield compared with an untreated control in field conditions with pasmo disease pressure in a previous study in Manitoba (8). Benomyl fungicide has been shown to significantly decrease pasmo severity and increase yield compared with untreated controls in Manitoba (8) and South Dakota (1). Benomyl is no longer under production and is not commercially available in the United States. Currently, the only fungicide registered for foliar application on flax in the United States is sulfur. From our results presented herein, registration of other fungicides on flax, such as azoxystrobin and prothioconazole, may give growers better fungicide management options for pasmo. Because of the risk of resistance developing to these fungicide chemistries, these two fungicides would work well as rotational or tank-mix partners to reduce the risk of developing fungicide resistance. Although beneficial effects of some fungicides were observed in our trials, the lowest level of pasmo observed was still quite high $(65 \%$ for azoxystrobin). Because $S$. linicolainfected debris were present in the field as an inoculum source, disease pressure was

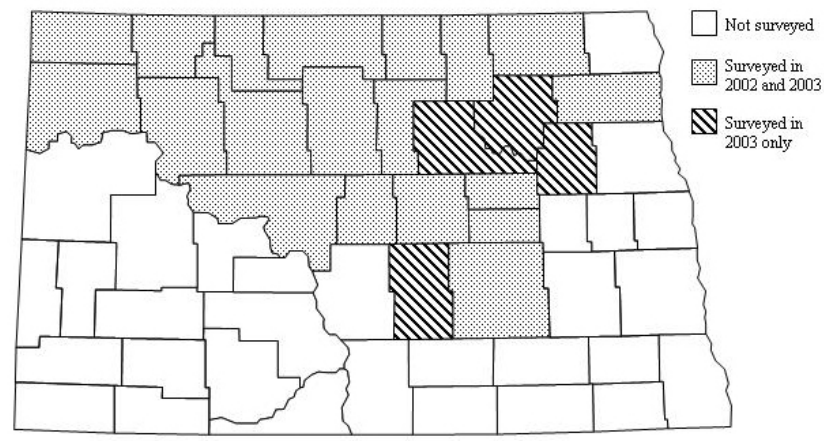

Fig. 1. North Dakota counties surveyed for pasmo in flax fields in 2002 and 2003. quite high and infection occurred very early. When fungicides were applied, the disease severity was already greater than $60 \%$ in all of the plots. When infection occurs early, earlier and multiple applications may be needed for season-long protection. More research is needed to evaluate fungicide application timings under natural disease pressure environments.

All four flax cultivars planted in our field studies were shown to be susceptible to pasmo. However, cv. Omega may be less susceptible than the other three cultivars used in the studies, as indicated by the significantly lower pasmo severity rating. Growers should determine which flax cultivars to plant by observing local yield data from cultivar trials and other economical reasons, such as monetary premiums for yellow-seeded versus brown-seeded flax.

Based on our results, pasmo is an important disease of flax in North Dakota, and its distribution is widespread throughout the flax-production region. Immediate practices that North Dakota flax growers can implement for pasmo management include planting properly cleaned, disease-free, and fungicide-treated seed; planting as early as possible; and following a crop rotation of 3 to 4 years between flax crops (4). If new fungicides become registered for use on flax in the United States, they could become a potential tool for pasmo management if they are economically feasible.

Table 3. Effect of fungicides on pasmo severity and flax yield at Langdon, ND in 2002 and 2003 combined

\begin{tabular}{lcc}
\hline Fungicide & $\begin{array}{c}\text { Pasmo } \\
\text { severity }(\%) \mathbf{a}\end{array}$ & $\begin{array}{c}\text { Yield } \\
(\mathbf{k g} / \mathbf{h a})\end{array}$ \\
\hline Untreated control & 77 & 471 \\
Azoxystrobin & 65 & 708 \\
Prothioconazole & 73 & 575 \\
Sulfur & 72 & 507 \\
Vinclozolin & 74 & 435 \\
LSD $_{0.05}{ }^{\mathrm{b}}$ & 5 & 103 \\
\hline
\end{tabular}

${ }^{a}$ Pasmo severity was calculated as (length of plant with symptomatic leaves from the soil line/total length of plant in centimeters) $\times 100$.

${ }^{b}$ Fisher's protected least significant difference (LSD) was used to compare means where $\alpha=0.05$.

Table 4. Effect of flax cultivar on pasmo severity and yield at Langdon, ND in 2002 and 2003 combined

\begin{tabular}{lcc}
\hline Cultivar & $\begin{array}{c}\text { Pasmo } \\
\text { severity }(\%)\end{array}$ & $\begin{array}{c}\text { Yield } \\
(\mathbf{k g} / \mathbf{h a})\end{array}$ \\
\hline Omega & 65 & 326 \\
Webster & 71 & 394 \\
AC Watson & 78 & 666 \\
Rahab 94 & 74 & 771 \\
LSD $_{0.05}{ }^{\mathrm{b}}$ & 4 & 92 \\
\hline
\end{tabular}

a Pasmo severity was calculated as (length of plant with symptomatic leaves from the soil line/total length of plant in $\mathrm{cm}) \times 100$.

${ }^{b}$ Fisher's protected least significant difference (LSD) was used to compare means where $\alpha=0.05$. 
ACKNOWLEDGMENTS

We thank L. Atkinson, N. Carlson, M. Gregoire, B. Klein, P. Metzger, K. Novak, C. Rylander, H. Semler, C. Stroklund, and N. Zahradka for their help with the field surveys.

\section{LITERATURE CITED}

1. Ferguson, M. W., Lay, C. L., and Evenson, P. D. 1987. Effect of pasmo disease on flower production and yield components of flax. Phytopathology 77:805-808.

2. Holb, I. J., De Jong, P. F., and Heijne, B. 2003. Efficacy and phytotoxicity of lime sulphur in organic apple production. Ann. Appl. Biol. 142:225-233.

3. Rashid, K. Y. 2001. Pasmo disease in flax: impact on yield and potential control methods. (Abstr.) Can. J. Plant Pathol. 23:204.

4. Rashid, K. Y. 2003. Diseases of flax. Pages 147-154 in: Diseases of Field Crops in Canada, 3rd ed. K. L. Bailey, B. D. Gossen, R. K. Gugel, and R. A. A. Morrall, eds. Uni- versity Extension Press, Saskatoon, SK, Canada.

5. Rashid, K. Y., Desjardins, M., Duguid, S., and Kaminski, D. A. 2002. Diseases of flax in Manitoba and Saskatchewan in 2001. Can. Plant Dis. Surv. 82:107-108.

6. Rashid, K. Y., Desjardins, M., Duguid, S., and Kaminski, D. A. 2003. Diseases of flax in Manitoba and Saskatchewan in 2002. Can. Plant Dis. Surv. 83:117-118.

7. Rashid, K. Y., Desjardins, M., Duguid, S., and Platford, R. G. 2001. Diseases of flax in Manitoba and Saskatchewan in 2000. Can. Plant Dis. Surv. 81:123-125.

8. Rashid, K. Y. and Kenaschuk, E. O. 1998. Yield loss in flax from pasmo and efficacy of chemical control. Pages 125-128 in: Proc. 57th Flax Inst. United States, Fargo, ND.

9. Rashid, K. Y., Kenaschuk, E. O., Duguid, S., and Platford, R. G. 2000. Diseases of flax in Manitoba and Eastern Saskatchewan in 1999. Can. Plant Dis. Surv. 80:92-94.
10. Rashid, K. Y., Kenaschuk, E. O., and Platford, R. G. 1997. Diseases of flax in Manitoba in 1996. Can. Plant Dis. Surv. 77:78-79.

11. Rashid, K. Y., Kenaschuk, E. O., and Platford, R. G. 1998. Diseases of flax in Manitoba in 1997 and first report of powdery mildew on flax in Western Canada. Can. Plant Dis. Surv. 78:100-101.

12. Rashid, K. Y., Kenaschuk, E. O., and Platford, R. G. 1999. Diseases of flax in Manitoba and Eastern Saskatchewan in 1998. Can. Plant Dis. Surv. 79:122-123.

13. Smith, V. L. 2003. Evaluation of Phyton 27 for control of dogwood anthracnose and powdery mildew, 2002. Fungicide and Nematicide Tests (online). Report 58:OT036. DOI: 10.1094/FN58. American Phytopathological Society, St. Paul, MN

14. Sokhi, S. S., Grewal, R. K., Thind, T. S., and Singh, P. P. 1990. Toxic effects of some fungicides on muskmelon. Plant Dis. Res. 5:77-80. 